\title{
EFFECTS OF PROBIOTICS AND PHYTOEXTRACTS ON GROWTH AND IMMUNOMODULATING PERFORMANCES OF BROILER CHICKENS
}

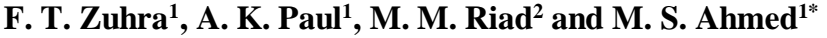 \\ ${ }^{1}$ Department of Medicine, Surgery and Obstetrics, ${ }^{2}$ Department of Basic Science, Faculty of Animal Science and \\ Veterinary Medicine, Patuakhali Science and Technology University, Barisal-8210, Bangladesh.
}

\begin{abstract}
An investigation was carried out to find out the effects of probiotics and phytoextracts (Korolla- bitter melon, Triphalatraditional three herbal components and Safi-commercial polyherbal products) on growth, hemato-biochemical (TEC, TLC, ESR, Hb concentration, PCV, ALT, AST, Cholesterol, Tryglyceride, HDL and LDL) and immunomodulating performance of broiler chickens. The study was performed from February to April, 2017. A total of 150, seven-days-old broiler chicks were divided into five (05) groups using 30 chicks in each group. The group A was designated as control group (without probiotics and phytoextracts), with probiotics (Exolution ${ }^{\circledR}$ ) Group B, with phytoextract (Korolla-bitter melon) Group C, Triphalatraditional three herbal components Group D and Safi Group E. Chicks were reared for 35 days and body weight were measured on weekly basis. Broilers were sacrificed at the end of 35 days and blood samples were taken for hematological analysis. Serum samples were also taken for biochemical tests. Broilers in all treatment groups were necropsied at the end of the experiment to observe and determine the weight of the gross lymphoid organs (spleen, thymus and bursa of Fabricious). Both body weight gain, hematological parameters like TEC, TLC, Hb concentration and PCV values and size of lymphoid organs (spleen, thymus, Bursa of Fabricious) were increased in birds supplemented with probiotics and phytoextracts as compared with control group. In biochemical parameters, AST and ALT values were decreased significantly $(\mathrm{p}<0.05$ and $\mathrm{p}<0.01$ ) in groups B, C, D, E from that of the control group. The findings of the experiment would help us to assess the use of proper feed additives as healthy growth promoter and immunomodulator in broiler chickens.
\end{abstract}

Keywords: Probiotics, phytoextracts, broiler, growth, immunomodulator

\section{INTRODUCTION}

The poultry sub-sector is an important avenue in fostering agricultural growth and reduce malnutrition for the people in Bangladesh (Carlos et al., 2014). It is an integral part of farming system in Bangladesh including support services for about 6 million people (Ansarey et al., 2012). This sub-sector has provided as an attractive economic activity and indicating its importance for the entire economy. It has been reported that poultry meat alone contributes $37 \%$ of the total meat production and contributes about $22-27 \%$ of the total animal protein in Bangladesh (Prabakaran, 2003).

The production of broiler has grown dramatically in the past two decades and these improvements are largely depends on numerous research and breeding programs which further enhances feed utilization and growth rate of chicken. To achieve the optimum production, a number of feed additives like antibiotics, steroids, vitamin, minerals and other growth promoters have been used to improve the performance of broiler growth (Raha, 2009). Nowadays human beings are very much conscious of their health and their food quality. The demand for quality broilers without antibiotics, chemicals and growth promoters is now a great concern in the world (Sarker et al., 2014).

Probiotics are live microorganisms which administered in adequate amounts confer a health benefit on the host .It includes live bacteria, yeast, microbial metabolites and $\mathrm{pH}$ adjusters, which contribute to maintain balance in intestinal microflora (Islam et al., 2004) leading to beneficial effects to the animal and antagonistic to harmful microbes. The mono or mixed probiotics substitutes for antibiotics in broiler industry have become an arena of great interest.

*Corresponding e-mail address: selimpstu476@pstu.ac.bd 


\section{Zuhra and others}

Plants are the oldest friends of mankind. In modern animal feeding, plant extracts have gained interest in animal feed ration (Charis, 2000). Medicinal plants compete with synthetic drugs, and the majority has no residual effects (Tipu et al., 2006). Medicinal plants and its products continue to be an important therapeutic aid for alleviating the ailments of human beings as well as poultry (Joseph et al., 2010; Singh et al., 2012).

Momordica charantia (M. charantia), also known as bitter melon, korolla, balsam pear, or bitter gourd, is a popular plant used for the treating various disease in the world (Cefalu et al., 2008 ; Cousens, 2008). The extract of bitter melon can also be used as a broad-spectrum antibacterial agent to fight off infectious agents such as Escherichia coli, Salmonella sp, Staphylococcus aureus, Staphylococcus sp, Pseudomonas sp and Streptobaccilus sp (Saeed et al., 2005).

Triphala (tri $=$ three and phala $=$ fruits), is an ayurvedic preparation composed of three equal proportions of herbal fruits native to the Indian subcontinent: viz. Terminalia chebula, Phyllanthus emblica, and Terminalia belerica. It has been reported that various applications of triphala in medical field used as laxative, digestive stimulation, anti inflammatory, antioxidant activity, lower cholesterol, reduces tumor size and improves liver function (Kumar et al., 2010; Sandhya et al., 2006). It also inhibits the growth of Gram-positive and Gramnegative bacteria (Biradar et al., 2008).

Safi is a versatile polypharmaceutical herbal medicine prepared with valuable medicinal plants that cleanses the entire system of the body. It is also useful as a diuretic and preventing problems arises from change of weather. It has been reported that safi also works against blood impurities, skin diseases, constipation, hyper cholesterolaemia, epistaxis etc in human.

However, it is not clear whether these phyto extracts have any antimicrobial effect or growth promoting effects in broiler chicken. So, present study was under taken to consider the following objectives: to investigate the effects of probiotics and plant extracts as feed additives on growth performance of broiler chicks; to determine the effects of probiotics and phyto feed additives supplementation on hemato-biochemical parameters such as Total Erythrocyte Count (TEC), Total leukocyte count (TLC), Packed Cell Volume (PCV), Haemoglobin (Hb) concentration, Erythrocyte Sedimentation Rate (ESR), Serum alanine aminotransferase (ALT), Serum aspertate transaminase (AST), Tryglyceride, Cholesterol, LDL and HDL; and to assess the immune activity of chicken by observing gross changes of lymphoid organs (thymus, bursa of Fabricious and spleen) and counting total leukocyte per unit volume of blood.

\section{MATERIALS AND METHODS}

The study was conducted at the Department of Medicine, Surgery and Obstetrics, Patuakhali science and Technology University, Babuganj, Barisal during the period from February, 2017 to April, 2017. To complete the research work following steps were followed.

\section{Management of experimental shed and broilers}

At first the shed for rearing broiler chickens (experimental poultry shed at ANSVM campus, PSTU was managed by Department of Medicine, Surgery and Obstetrics) were properly prepared. The pens were thoroughly cleaned, white washed and disinfected before keeping the experimental chick in the shed. A total of 100 DOC (Day Old Chicks) were purchased from a local dealer of Paragon Poultry \& Hatchery Ltd. Then the DOC (Day Old Chicks) was managed carefully. All the birds were provided same management conditions like floor space, temperature, relative humidity, ventilation and light. Immediately after unloading from the chick boxes, the chicks were provided vitamin-C and glucose to prevent the occurrence of stress occurring during transportation.

The broiler chicks were kept in the same compartment for 7 days and brooding temperature were correctly maintained. Optimum light was provided daily throughout the experimental period. The chicks were brooded at $35^{\circ} \mathrm{C}$ during first week and thereafter; the temperature was reduced by $3^{\circ} \mathrm{C}$ in every week until the temperature reached to the room temperature i.e., $25 \pm 1^{\circ} \mathrm{C}$. All the groups were reared under the similar conditions of temperature, humidity, light, ventilation and floor space. The litter management was also done very carefully. The starter and finisher broiler rations were supplied to the broiler chicken appropriately. A weighed amount of the ration was offered to the birds twice a day and the left over feed was collected to calculate feed consumption of the individual broiler. 


\section{Routine management}

The following management procedures were carried out during the experimental period.

\section{Litter management}

Fresh and dried rice husk collected from local rice mill was used as litter material. The depth of litter was $3 \mathrm{~cm}$. The litter material was disinfected with Vircon $(5 \mathrm{~g} /$ liter water) solution. The litter was stirred three times in a week from 14 days and onwards to avoid cake formation. It was replaced by new litter once was found damp partially or fully.

\section{Immunization of birds}

The birds were vaccinated against Newcastle disease (Ranikhet) and infectious bursal disease (Gumboro).

\section{Collection and processing of Korolla}

Korolla (Momordica charantia) were bought from local market for preparation of korolla extract to determine its efficacy as growth promoter on broilers. Mature and diseased free korolla were collected from local market.

\section{Preparation of Korolla extracts}

At first korolla was washed with distilled water. After washing, 50 gm korolla was measured by weighing balance and properly grinded with mortar and pestle. Then grinded korolla was taken in glass beaker and distilled water was added up to the 100 marks. In this process $50 \%$ korolla solution (stock solution) were prepared and properly filtered. Finally it was stored in a refrigerator at $4^{\circ} \mathrm{C}$ to maintain the active ingredients. From this stock solution $3 \mathrm{ml}$ was added with $100 \mathrm{ml}$ drinking water as a regular dose. Thus the final concentration of korolla extract in the drinking water of the treatment group was $3 \%$.

\section{Collection of probiotics}

Superbiotics (Exolution ${ }^{\circledR}$ ) was collected from local market, which is available in the market by ACI Agrovet Limited. Each gm of superbiotic contains Bacillus subtilis min. $1 \times 10^{6} \mathrm{cfu}$ with specific Bacteriophage q.s. to 1 $\mathrm{gm}$ ) and administrated $2 \mathrm{gm} /$ lit of water for $28^{\text {th }}$ days from the starting time of the experiment.

\section{Collection of Triphala}

Triphala was collected from local market manufactured by Humdard Laboratories Bangladesh. It consists of Amalki, Haritaki and Bahera (Terminalia chebula, Phyllanthus emblica, and Terminalia belerica.) and administrated $3 \mathrm{gm} / \mathrm{lit}$ of drinking water for $28^{\text {th }}$ days.

\section{Collection of Safi}

Safi was collected from local market manufactured by Humdard Laboratories Bangladesh.

\section{Experimental design}

After 7 days all the 100 broiler chicks were randomly divided into 5 groups (A, B, C, D and E) for assessing the efficacy of superbiotics, korolla (bitter melon) extract, triphala and safi as growth promoter on broilers. The commercial broiler ration and commercial superbiotics (Exolution $\left.{ }^{\circledR}\right)$, Korolla, Triphala and Safi were purchased from the local market. Group-A: Fed with commercial broiler ration and fresh drinking water; GroupB:Commercial superbiotics (Exolution $®)$ ) $2 \mathrm{gm} / \mathrm{L}$ drinking water plus commercial broiler ration for 28 days; Croup-C: Korolla @3ml/L drinking water plus commercial broiler ration for $28^{\text {th }}$ days; Group- D: Triphala @ $3 \mathrm{gm} / \mathrm{L}$ drinking water plus commercial broiler ration for 28 days; Group- E : Safi @ 3 ml/L drinking water plus commercial broiler ration for 28 days. All the chicks of treated and control groups were closely observed for 35 days and following parameters were also studied.

\section{Recording body weight}

The effects of phytoextracts and superbiotics on body weight of broilers were recorded using digital balance before and after treatment. The body weight and feed conversion ratio were measured at 7 days interval up to 35 days of age.

\section{Determination of hematobiochemical parameters}

Blood samples were collected from the wing vein of chicken of both control and treatment groups on $35^{\text {th }}$ day and determine the effects of phyto extracts and superbiotics on hematobiochemical parameters. 
The principles and procedures of hematobiochemical examinations are as follows:

Total Erythrocyte Count (TEC)

Total erythrocyte count was done following the method described by Lamberg and Rothstein (1977). Wellmixed blood sample was drawn with red blood cell diluting pipette and immediately filled with the red cell diluting fluid (Hayem's solution). Then the total number of RBC was calculated as number of cells counted $\mathrm{x}$ 10,000 and the result was expressed in million/ $\mu$ of blood.

\section{Total Leukocyte Count (TLC)}

The experiment was performed by Lamberg and Rothstein (1977). A sample of whole blood was mixed with diluents, which lyses red cells and stains nuclei of white blood cells. The white blood cells (WBC) were counted in a hemocytometer counting chamber under the microscope and result is expressed as total number of leukocytes per $\mu \mathrm{l}$ of blood or per liter of blood.

\section{Hemoglobin Concentration (Hb)}

Well-homogenized blood sample was then drawn into the Sahli pipette and the blood of the pipette was immediately transferred into the graduated tube containing hydrochloric acid. This blood and acid were thoroughly mixed by stirring with a glass stirrer. The tube containing acid hematin mixture was added water drop by drop. The solution was mixed well with a glass stirrer until the color of the mixture resembled to the standard color of the comparator. The result was read in daylight by observing the height of the liquid in the tube considering the lower meniscus of the liquid column. The result was then expressed in $\mathrm{g} \%$. The above procedure was matched by the Hellige hemometer method as described by Lamberg and Rothstein (1977).

\section{Packed Cell Volume (PCV)}

The citrated well mixed blood sample was drawn into special loading pipette (Wintrobe pipette) and pipette was filled from the bottom by pressing the rubber bulb of the pipette. Then the Wintrobe hematocrit tube was placed in the centrifuge machine and was centrifuged for 30 minutes at $3000 \mathrm{rpm}$. The hematocrite or PCV was recorded by reading the graduation mark. The percent volume occupied by the hematocrit was calculated by using the following formula as described by Lamberg and Rothstein (1977).

$$
\text { PCV\% }=\frac{\text { Heightof the red cell volumein } \mathrm{cm}}{\text { Height of totalbloodin } \mathrm{cm}} \times 100
$$

\section{Erythrocyte Sedimentation Rate (ESR)}

The fresh anticoagulant blood was taken into the Wintrobe hematocrit tube. The filled tube was placed vertically undisturbed on the wooden rack for one hour. After one hour the ESR was recorded from the top of the pipette. The result was expressed in $\mathrm{mm} / \mathrm{in} 1^{\text {st }}$ hour.

\section{Cholesterol}

At first 10 micro liters sample was taken in each test tube and $1 \mathrm{ml}$ sample was thoroughly by stirring with a glass stirrer. The result was read in EMP biochemical Analyser® machine. The result was expressed in mg/dl. According to the National Cholesterol Education Program, the desirable blood cholesterol level is $<200 \mathrm{mg} / \mathrm{dl}$. The borderline high blood cholesterol level is $200-239 \mathrm{mg} / \mathrm{dl}$ and high blood cholesterol level is $>240 \mathrm{mg} / \mathrm{dl}$. The above procedure was performed according to the manufacturer instructions (Crescent Diagnostics ${ }^{\circledR}$ ).

\section{Tryglyceride}

The working reagent was prepared after mixing $\mathrm{R}_{1}$ reagent with 100 parts of $\mathrm{R} 2$ reagent that mixed thoroughly. The result was read in EMP Biochemical Analyser® and result was expressed in mg/dl. The experiment procedure was done according the manufacturer instructions (Crescent Diagnostics ${ }^{\circledR}$ ).

\section{HDL (High Density Lipoprotein)}

At first $10 \mu \mathrm{l}$ sample and $1 \mathrm{ml}$ reagent were taken in the test tube mixed it thoroughly and allowed to stand for 10 minutes. $1 \mathrm{ml} \mathrm{R}_{1}$ mixed with $100 \mathrm{ml} \mathrm{R}$ and incubated for $5 \mathrm{~min}$ at $37^{0} \mathrm{c}$ temperature. The result was read in EMP Biochemical Analyser ${ }^{\circledR}$ machine and expressed in $\mathrm{mmol} / \mathrm{L}$. Above procedure was performed according to the manufacturer instructions (Crescent Diagnostics $®)$. 


\section{SGOT (AST)}

Taken 4 parts of reagent 1 with 1 part of reagent 2 and mixed it thoroughly with prepared monoreagent. The sample should be diluted $1+9$ with $0.9 \% \mathrm{NaCl}$ solution, then $200 \mathrm{ml}$ sample were properly added with $1 \mathrm{ml}$ monoreagent. Mixed it thoroughly and incubated approximately for $1 \mathrm{~min}$. After that reading was taken from EMP Biochemical Analyser®. Above procedure was also done according to the manufacturer instructions (Crescent Diagnostics $\left.{ }^{\circledR}\right)$.

\section{SGPT (ALT)}

Taken 4 parts of reagent 1 with 1 part of reagent 2 and mixed it thoroughly to prepare monoreagent. The sample should be diluted $1+9$ with $0.9 \% \mathrm{NaCl}$ solution, then $200 \mathrm{ml}$ sample were properly added with $1 \mathrm{ml}$ monoreagent. Mixed it thoroughly and incubated approximately for $1 \mathrm{~min}$. After that reading was taken from EMP Biochemical Analyser ${ }^{\circledR}$. Above procedure was also done according to the manufacturer instructions (Crescent Diagnostics $\left.{ }^{\circledR}\right)$.

\section{Feed consumption}

Feed consumption is the amount of feed consumed every week; it was calculated for each treatment at weekly basis. At the end of the week, the residual amount of feed was weight and subtracted from the known weight of feed at the beginning of week. The feed was divided by the total number of birds.

\section{Body weight gain}

Body weight was measured for all birds at the beginning of the experiment, and it was repeated weekly at the beginning of the week in the same time. Live weight gain was calculated by subtraction of live weight at the beginning of the week from the live body weight of the next week.

Weight gain $=$ Live weight - Initial weight

\section{Postmortem Examination}

Five broilers from each group were slaughtered to see if there were any pathological changes present on $35^{\text {th }}$ day after treatment. There were no significant pathological changes in any internal organs of the broilers of treatment group. To estimate the immune activity of lymphoid organs (thymus, spleen and bursa of Fabricious) were collected and compared with control group of chicken.

\section{Biosecurity and sanitation}

Proper hygienic and sanitation programs were followed to prevent the outbreak of infectious diseases.

\section{Statistical Analysis}

The data were analyzed statistically between control and treated groups of chicken by Student's $t$-test.

\section{RESULTS AND DISCUSSION}

\section{Effects of probiotics and phytoextracts on body weight of broilers}

Effects on body weight of different groups of broilers are presented in Table 1. Body weight on day 7 of age (1st day of study) was observed that the body weight in control group A was $0.574 \pm 0.015$, in the treatment group B (Probiotics) was $0.5944 \pm 0.004 \mathrm{gm}$, in group C (Korolla) was $0.585 \pm 0.007 \mathrm{gm}$ and in group D (Triphala) was $0.580 \pm 0.003701 \mathrm{gm}$ and in group E (Safi) was $0.577 \pm 0.017 \mathrm{gm}$. In this experiment, phtoextracts components (Korolla, Triphala, Safi) comparatively increase body weight than probiotics treated group.

Probiotics improve gut micro flora and positively influences local and systemic immune systems by secreting beneficial enzymes, organic acids, vitamin and non-toxic antibacterial substances (Jun et al., 2002; Dibner, 2004). It also successfully improves immune status of broiler chicks. Probiotics increases physiological activity and production performance of broiler chicken which support the recorded study (Rahman et al., 2013; Ahmed and Taghi, 2006; Kabir et al., 2004).

The non pharmacological products like prebiotics, probiotics, organic acids, essential oils, medicinal plants or parts of plants were used as feed additives which are alternatives to antibiotics as growth stimulators (Simon $e t$ al., 2001). It has been reported that Korolla (Momordica charantia) have antidiabetic effect, inhibit unwanted cell proliferation, hypoglycemic (reduce blood glucose level) and heptoprotective effects in human body (Rahman et al., 2011; Singh et al., 2008; Taylor et al., 2002 ; Saeed et al., 2010 ; Budrat et al., 2008). The beneficial effect of Korolla on animals and birds didn't study yet. In our study recorded that extract of Korolla as 


\section{Zuhra and others}

feed additives improve the body weight of broiler chicken which was in support of previous study in human cases. The plant extract Triphala have been used as antioxidant, gastroprotective, hepatoprotective, antifungal and antibiotic effect in human medicine (Sabu and Kuttan, 2002; Nariya et al., 2011; Jose and Kuttan, 2006; Bajaj and Tandon, 2011). Unlikely there is no recorded data on animal and bird cases. In performed study, Triphala extract as feed additives significantly enhances body weight than control group of birds which might be in support of Sabu and Kuttan, (2002) and Nariya et al. (2011). It might have similar positive effects (gastroproetective, hepatoprotective and antioxidant) in the birds like human individual.

The herbal extract Safi (Humdard Lab. Bangladesh.) usually used to treat liver disease, constipation and dermatitis according to manufacturer instruction. It also has no performed study on human and animals. But in our experiment it has been recorded that Safi as feed additives increases feed efficiency and body weight of broiler chicken. So it might have hepatic protective effect and increases digestibility in broilers. Sarker et al. (2014) reported that neem leaves act as growth promoting effect in broiler birds. Neem extract is the one of the basic component of Safi syrup and recorded data support the findings of Sarker et al. (2014).

Table 1. Effects of probiotics and phyto extracts on body weight (gm) (Mean \pm SD) in broilers on 28th day of experiment

\begin{tabular}{lcc|cc}
\hline Groups & \multicolumn{4}{c}{ Mean $\pm \mathrm{SD}(\mathrm{Kg})$} \\
\cline { 2 - 5 } & \multicolumn{2}{c}{ Pre treatment } & Post treatment \\
\cline { 2 - 5 } & $1^{\text {st }}$ day of experiment & $\begin{array}{c}7^{\text {th }} \text { days of } \\
\text { experiment }\end{array}$ & $\begin{array}{c}14^{\text {th }} \text { day of } \\
\text { experiment }\end{array}$ & $\begin{array}{c}21^{\text {st }} \text { day of } \\
\text { experiment }\end{array}$ \\
\cline { 2 - 5 } & Body weight & Body weight & Body weight & Body weight \\
\hline (A) Control & $0.570 \pm 0.01$ & $1.05 \pm 0.01$ & $1.65 \pm 0.01$ & $2.06 \pm 0.07$ \\
(B) Probiotics & $0.594 \pm 0.00$ & $1.09 \pm 0.04$ & $1.69 \pm 0.01$ & $2.18 \pm 0.08$ \\
(C) Korolla & $0.585 \pm 0.00$ & $1.09 \pm 0.01 *$ & $1.75 \pm 0.01$ & $2.36 \pm 0.17$ \\
(D) Triphala & $0.580 \pm 0.00$ & $1.07 \pm 0.02$ & $1.71 \pm 0.01^{* *}$ & $2.30 \pm 0.02^{* *}$ \\
(E) Safi & $0.577 \pm 0.01$ & $1.05 \pm 0.02$ & $1.69 \pm 0.00^{* *}$ & $2.28 \pm 0.20$ \\
\hline
\end{tabular}

** = Significant at $1 \%(\mathrm{p}<0.01)$ level of probability.

$*=$ Significant at $5 \%(\mathrm{p}<0.05)$ level of probability.

\section{Effects of probiotics and phytoextracts on hematological parameter}

Effects of probiotics and phyto extracts (Korolla, Triphala, Safi) increases total erythrocyte count (TEC), total leukocyte count (TLC) and hemoglobin concentration in broiler chicken shown in Table 2. Rahman et al. (2013) showed that probiotics as growth promoter increases growth performance, erythrocyte count and hemoglobin concentration in broiler. Sarkar et al. (2014) also showed that probiotics as feed additives increase the total erythrocyte count and hemoglobin concentration significantly in treatment group. These published data similar to performed study.

In our study, most of the phytoextracts component significantly increases total erythrocyte count and hemoglobin concentration and reduces ESR time/hr shown in Table 2. It has been reported that feeding broiler with Nishyinda, black pepper and cinnamon extract as feed additives increases total erythrocyte count and hemoglobin by Molla et al. (2012). Mahejabin et al. (2015) reported that neem, turmeric and papaya leaf extracts also increases TEC and hemoglobin concentration, which are in support of recorded data. Sorwar et al. (2016) also reported that kalo zeera seeds and papaya leafs also increases the hemoglobin concentration, TEC and decreases ESR which were more or less similar to recorded study. Plant extracts and their fruits used as blood purifier, antioxidants and heptoprotective agents in the body (Bajaj and Tandon, 2011 and Rahman et al., 2011). Triphala, Korolla and Safi in treatment group of chickens might have similar function and support the findings of (Bajaj and Tandon, 2011; Rahman et al., 2011). 
Table 2. Effects on hematological parameters (Mean \pm SD) in broilers on $28^{\text {th }}$ day of experiment

\begin{tabular}{l|c|c|c|c|c}
\hline Groups & $\begin{array}{c}\text { TEC } \\
\text { Millions } / \mathrm{mm} 3\end{array}$ & $\begin{array}{c}\text { TLC } \\
\left(\times 10^{3} / \mathrm{ml}\right)\end{array}$ & $\mathrm{Hb}(\mathrm{gm} / \mathrm{dl})$ & PCV $(\%)$ & $\begin{array}{c}\text { ESR }\left(\mathrm{mm} \mathrm{in} 1^{\text {st }}\right. \\
\text { hour }\end{array}$ \\
\hline A (Control) & $3.61 \pm 0.15$ & $4.12 \pm 0.17$ & $10 \pm 1.58$ & $27.6 \pm 3.91$ & $3.75 \pm 0.23$ \\
B (Probiotics) & $3.63 \pm 0.13$ & $4.14 \pm 0.19$ & $13.2 \pm 1.09^{*}$ & $30.2 \pm 4.76$ & $3.15 \pm 0.20$ \\
C (Korolla) & $3.96 \pm 0.06^{* *}$ & $4.28 \pm 0.03^{* *}$ & $15.4 \pm 1.14^{* *}$ & $33.8 \pm 2.58^{*}$ & $2.86 \pm 0.57$ \\
D (Triphala) & $3.79 \pm 0.14$ & $4.30 \pm 0.05^{* *}$ & $14.8 \pm 1.30^{* *}$ & $28.8 \pm 1.92$ & $2.84 \pm 0.42$ \\
E (Safi) & $3.78 \pm 0.12$ & $4.15 \pm 0.15$ & $13.2 \pm 2.58$ & $28.6 \pm 3.20$ & $2.80 \pm 0.24^{* *}$ \\
\hline
\end{tabular}

** = Significant at $1 \%(\mathrm{p}<0.01)$ level of probability

$*=$ Significant at $5 \%(\mathrm{p}<0.05)$ level of probability.

\section{Effects of probiotics and phytoextracts on biochemical parameters}

The probiotics and phtoextracts feeding to broiler as feed additives significantly changes biochemical parameter of liver function enzymes and lipid profile in serum content of blood shown in Table 3. Rahman et al. (2013) and Pazhanivel and Balachandran (2014) reported that serum ALT level was significantly reduced in chicken with probiotics and phytoextracts treated group, respectively. The recorded present study also supported by Sarker et al. (2014). Kanjilal et al. (2014) also reported that feeding probiotics as feed additives decreases liver function enzyme (AST and ALT) and similar to performed study.

Triphala treatment significantly reduce serum cholesterol and LDL level in human (Saravanan et al., 2007), which was in support to present study in broiler chickens. Attia et al. (2017) also found that phytoextract blend treated group increases the serum HDL level and reduces the serum cholesterol and LDL level of broiler chicken, which was inclined to our present data.

Table 3. Biocehmical parameter (Mean \pm SD) in broilers on 28th day of experiment after treating with probiotics and phyto extracts (Korolla, Triphala and Safi)

\begin{tabular}{l|c|c|c|c|c|c|c}
\hline Group & $\begin{array}{c}\text { No. of } \\
\text { birds }\end{array}$ & AST (U/L) & ALT (U/L) & CHOL & Tryglyceride & HDL & LDL \\
\hline A (Control) & 20 & $358.3 \pm 0.21$ & $5.3 \pm 0.21$ & $177.33 \pm 19.81^{*}$ & $48.71 \pm 1.23$ & $65.3 \pm 1.72$ & $90.08 \pm 1.62$ \\
\hline B (Probiotics) & 20 & $356.3 \pm 0.09^{* *}$ & $5.0 \pm 0.09$ & $146.03 \pm 10.54$ & $46.5 \pm 1.64$ & $66.5 \pm 1.87$ & $86.83 \pm 2.63$ \\
\hline C (Korolla) & 20 & $350.1 \pm 0.12^{* *}$ & $4.5 .1 \pm 0.12 * *$ & $87.18 \pm 3.01 * *$ & $38.2 \pm 1.92$ & $73.4 \pm 1.81 * *$ & $66.67 \pm 4.96$ \\
\hline D (Triphala) & 20 & $348.3 \pm 0.24 *$ & $4.3 \pm 0.24 * *$ & $91.6 \pm 2.7$ & $42.2 \pm 1.3 * *$ & $\begin{array}{c}70.83 \pm 1.47 * \\
*\end{array}$ & $65.83 \pm 2.78$ \\
\hline E (Safi) & 20 & $347.1 \pm 0.21 *$ & $4.8 \pm 0.21 *$ & $90.8 \pm 0.8$ & $45 \pm 1.58^{* *}$ & $67.3 \pm 1.63$ & $73.67 \pm 2.87$ \\
\hline
\end{tabular}

$*=$ Significant at $5 \%(\mathrm{p}<0.05)$ level of probability

$* *=$ Significant at $1 \%(\mathrm{p}<0.01)$ level of probability.

\section{Immunomodulating effects of probiotics and phytoextracts on gross changes of lymphoid organs and total leukocyte count.}

The effects of probiotics and phytoextracts as feed additives in broilers increase in size of lymphoid organs (spleen, thymus, bursa of Fabricious) and total leukocyte count as compared with control group shown in Table 2 and Table 4. Probiotics as feed additives increases T cell proliferation of broilers (Asqari et al., 2016). Shewita and Taha, (2011) reported that black seed powder (Nigella sativa) as feed additives significantly increases the size of thymus and bursa of Fabricious, which support the present performed study study. Mufarrez, (2014) found no significant differences in the size of lymphoid organs in broiler chickens. All of these published reports imply that probiotics and phytoextracts as feed additives improve immunmoduation in broiler. 
Table 4. Gross changes (Mean \pm SD) of lymphoid organs in broilers on $28^{\text {th }}$ day of experiment after treating with probiotics and phyto extract (Korolla, Triphala and Safi)

\begin{tabular}{l|l|l|l}
\hline Group & Spleen & Thymus & Bursa of Fabricious \\
\hline A (Control) & $2.27 \pm 0.04$ & $2.02 \pm 0.08$ & $1.84 \pm 0.24$ \\
B (Probiotics) & $2.92 \pm 0.08$ & $4.28 \pm 0.46$ & $3 \pm 0.07$ \\
C (Korolla) & $3.04 \pm 0.11$ & $5.2 \pm 0.44$ & $4.1 \pm 0.15$ \\
D (Triphala) & $2.508 \pm 0.25$ & $5.94 \pm 0.25$ & $3.12 \pm 0.13$ \\
E (Safi) & $3.08 \pm 0.08$ & $5.898 \pm 0.23$ & $3.06 \pm 0.15$ \\
\hline
\end{tabular}

\section{ACKNOWLEDGEMENT}

The authors are grateful to the NSICT fellowship (National Science and Information and Communication Technology) for funding.

\section{REFERENCES}

1. Ahmed K and Taghi G (2006). Effect of probiotic on performance and immunocompetence in broiler. The Journal of Poultry Science 43: 296-300.

2. Ansarey FH (2012). Prospects of poultry industry in Bangladesh. Proceedings of the Seminar and Reception on Animal Husbandry Education and Profession in Bangladesh- A Journey of 50 Years, (AHEPB'12), Dhaka, Bangladesh, 62-65.

3. Asqari F, Madjd Z, Falak R, Bahar MA, Nasrabadi MH, Raiani M and Shekarabi M (2016). Probiotic feeding affects T cell populations in blood and lymphoid organs in chickens. Beneficial Microbes 7: 669-675.

4. Attia G, Hassanein E, El-Eraky W, El-Gamal M, Farahat M and Hernandez-Santana A (2017). Effect of dietary supplementation with a plant extract blend on the growth performance, lipid propile, immune response and carcass traits of broiler chickens. International Journal Poultry Science 16: 248-256.

5. Bajaj $\mathrm{N}$ and Tandon S (2011). The effect of Triphala and Chlorhexidine mouthwash on dental plaque, gingival inflammation, and microbialgrowth. International Journal of Ayurveda Research 2:29-36.

6. Biradar YS, Jagatap S, Khandelwal KR and Singhania SS (2008). Exploring of Antibacterial activity of Triphala Mashi- an Ayurvedic Formulation. Evidence-Based complementary Alternative Medicine 5:107-113.

7. Budrat P and Shotipruk A (2008). Extraction of phenolic compounds from fruits of bitter melon (Momordica charantia) with subcritical water extraction and antioxidant activities of these extracts. Chiang Mai Journal of Sciences 35:123-130.

8. Carlos A, Silva Da and Rankin M (2014). Contract Farming for Inclusive Market Access. Food and Agriculture Organization of the United Nations, Rome, Italy, Pages: 227.

9. Cefalu WT, Ye J and Wang ZQ (2008). Efficacy of dietary supplementation with botanicals on carbohydrate metabolism in humans. Endocrine, Metabolic and Immune Disorder Drugs Target 8:78-81.

10. Charis K (2000). A novel look at a classical approach of plant extracts. Feed Mix (special issue on Nutraceuticals), 19-21.

11. Cousens G (2008). There is a cure for diabetes: the tree of life 21 days program. California: North Atlantic Books, p191-192.

12. Dibner J (2004). Organic acids: can they replace antibiotic growth promotes? Feed International 25: 14-16.

13. Islam MW, Rahman MM, Kabir SML, Kamruzzaman SM and Islam MN (2004). Effects of probiotics supplementation on growth performance and certain haematobiochemical parameters in broiler chickens. Bangladesh Journal of Veterinary Medicine 2:39-43.

14. Jose K and Kuttan R (2006). Hepatoprotective activity of Emblicaofficinalis and Chyavanaprash. Journal of Ethnopharmacol 72:135-140.

15. Joseph B and Raj SJ (2010). Phytopharmacological properties of Ficus racemesa. International Journal of Pharmacological Sciences Review of Research 3:134-138.

16. Kabir SML, Rahman MM and Rahman M (2004). The dynamics of probiotics on growth performance and immune response in broilers. International Journal of Poultry Science 3: 361-364.

17. Kanjilal G, Akanda MR, Hasan MMI, Chowdhury MR, Islam MS, Howlader MMR and Hossain MA (2014). Potency of Protexin ${ }^{\circledR}$ (Mixed Probiotics) on hemato biochemical alteration of commercial broiler. American Journal of Phytomedicine and Clinical Therapeutics 2:650-659. 
18. Kumar MS, Kirubanandan S, Sripriya R and Sehgal PK (2010). Triphala incorporated collagen sponge-a smart biomaterial for infected dermal wound healing. Journal of Surgical Research 158:162-170.

19. Lamberg SL and Rothstein R (1977). Laboratory Manual of Hematology and Urinalysis. Avian Publishing Company, Inc, West Port Connecticut, Union of Soviet Socialist Republics.

20. Mahejabin N, Mostofa M, Akter F, Das S and Alam M (2015). Effects of neem, turmeric and papaya leaf extract mixture on growth performance of broilers. International Journal of Natural and Social Sciences 18:673-68.

21. Molla MR, Rahman MM, Akter F and Mostofa M (2012). Effects of Nishyinda, black pepper and cinnamon extract as growth promoter in broilers. The Bangladesh Veterinarian 29:69-77.

22. Mufarrez SIA (2014). Immune-responsiveness and performance of broiler chickens fed black cumin (Nigella sativa L.) powder. Journal of the Saudi Society of Agricultural Sciences 13:75-80.

23. Nariya MB, Shukla VJ, Ravishankar B, and Jain SM, (2011). Comparison of gastroprotective effects of triphala formulations on stress-induced ulcer in rats. Indian Journal of Pharmacological Sciences 73:682-7.

24. Prabakaran R (2003). Good practices in planning and management of integrated commercial poultry production in South Asia. FAO Animal Production and Health Paper 159, Food and Agriculture Organization of the United nations, Rome, Italy.

25. Raha SK (2009). Export Possibility of Broiler from Bangladesh. Economic Affairs 54.

26. Rahman IU, Basir M, Salman M, Idrees M and Khan MI (2011). Bitter melon (Momordica charantia) reduces serum sialic acid in type 2 diabetics: Evidence to delay the process of atherosclerosis. China Medicine 2:125-129.

27. Rahman MS, Mustari A, Salauddin M and Rahman MM (2013). Effects of probiotics and enzymes on growth performance and haematobiochemical parameters in broilers. Journal of Bangladesh Agricultural University 11: 111-118.

28. Sabu MC and Kuttan R (2002). Anti-diabetic activity of medicinal plants and its relationship with their antioxidant property. Journal of Ethnopharmacology 81:155-160.

29. Saeed MK, Shahzadi I, Ahmad I, Ahmad R, Shahzad K and Ashraf M (2010). Nutritional analysis and antioxidant activity of bitter gourd (Momordica charantia) from Pakistan. Pharmacologyonline 1:252-260.

30. Saeed S and Tariq P (2005). Antibacterial activities of Mentha piperita, Pisum sativum and Momordica charantia. Pakistan Journal of Botany 37:997-1001.

31. Sandhya T, Lathika KM, Pandey BN and Mishra KP (2006). Potential of traditional Ayurvedic Formulation, Triphala as a novel anticancer drug, Cancer Letters 231:206-214.

32. Saravanan S, Srikumar R, Manikandan S, Parthasarathi NJ and Devi RS (2007). Hypolipidemic effect of Triphala in experimentally induced hypocholesteremic rats. Yakugaku Zasshi Journal of the Pharmaceutical Society of Japan 127:385-8.

33. Sarker EH, Sharifuzzaman, Khokon JU, Rahman MA, Mostofa M and Rahman M (2014). Comparative efficacy of probiotic, neem leaves and vitamin $\mathrm{AD} 3 \mathrm{E}$ as a growth promoter on broilers. International Journal of Natural and Social Sciences 26-32.

34. Shewita RS and Taha AE (2011). Effect of dietary supplementation of different levels of black seed (Nigella sativa) on growth, performance, immunological, hematological and carcass parameters of broiler chicks. World Academy of Science Engineering and Technology 77:788-794.

35. Simon O, Jadamus A and Vahjen W (2001). Probiotic feed additives-effectiveness and expected modes of action. Journal of Animal and Feed Sciences 10:51-67.

36. Singh N, Gupta M, Sirohi P, and Varsha, (2008). Effects of alcoholic extract of Momordica charantia (Linn.) whole fruit powder on the pancreatic islets of alloxan diabetic albino rats. Journal of Environmental Biology 29:101-106.

37. Singh U, Singh S and Kochhar A (2012). Therapeutic potential of antidiabetic, neutraceuticals, Phytopharmacology 2:144-169.

38. Sorwar MG, Mostofa M, Hasan MN, Billah M and Rahman MT (2016). Effect of Kalo jeera seeds and papaya leaf supplementation on the performance of broiler Bangladesh. Journal of Veterinary Medicine 14:37-42.

39. Taylor L (2002). Herbal secrets of the rainforest. In: Texas A, editor. Bitter melon (Momordica charantia) 2nd edition USA: Sage Press, pp. 1-100.

40. Tipu MA, Akhtar MS, Anjum MI and Raja ML (2006). New dimension of medicinal plants as animal feed, Pakistan Veterinary Journal 26:144-148. 